\title{
EFFECT OF MYCOTOXIN ON REPRODUCTIVE PERFORMANCE IN DAIRY CATTLE
}

\author{
MONA A. MAHMOUD*; GHATTAS T.A.; AMAL Z.A. LEIL ${ }^{* *}$ and ABED ELAZIZ M.Z ${ }^{* * *}$ \\ *Biology of Reproduction Dept., Giza. \\ **Field Investigation Dept., Giza. \\ ***Pathology Dept. Animal Reproduction Research Institute, Giza.
}

Received at: 30/6/2013

\section{ABSTRACT}

The present study was determined the effect of combined mycotoxins caused by Aflatoxin and zearalenone exposure on reproductive performance and their relation to the incidence of ovarian cysts in dairy cattle. The present study used 28 lactating cows kept at dairy farm in Dakahlia governorate. Cows were classified into two groups First group (10 cows) were received ration where the percentage

Accepted: 21/8/2013 of aflatoxin and zearalenone not exceed permissible limit which is (5 ppb and 200 ppb respectively) and show normal estrous behavior and have mature large follicles $>22 \mathrm{~mm}<25 \mathrm{~mm}$ in diameter and have corpus luteum. The second group (18 cows) received ration containing aflatoxin which found exceed permissible limit (19.7 ppb) and zearalenone which was present at high levels (400 ppb), these cows exhibit"constant" estrus (nymphomania), excessive vaginal discharge, until day 45 postpartium and have ovarian cysts based on the presence of follicular structure ( $\geq 25 \mathrm{~mm}$ in diameter) with anovulation and the absence of corpus luteum. Blood samples was collected from each cow around 45 days postpartium for evaluation of serum progesterone $\left(\mathrm{P}_{4}\right)$, estrogen $\left(\mathrm{E}_{2}\right)$, Luteinizing hormone $(\mathrm{LH})$, triiodothyronine $\left(\mathrm{T}_{3}\right)$, thyroxin $\left(\mathrm{T}_{4}\right)$, prolactin (PRL) total protein, calcium, inorganic phosphorus, Liver enzymatic activities alanine aminotransferase (ALT) and aspartate aminotransferase (AST) immunologlobins (IgG, IgM, IgA). The results of hormonal assay showed significant increase $(\mathrm{p}<0.05)$ in levels of prolactin and estrogen, while levels of LH, progestone, T3 and T4 showed significant decrease $(p<0.05)$ in cows received contaminated ration with zearalenone and aflatoxins in compared with control one. Regarding to results of biochemical and immunological parameters revealed a significant increase $(\mathrm{p}<0.05)$ in enzymatic activities (AST), (ALT), while total protein, calcium, inorganic phosphorus and immunological parameters (IgG, IgM, IgA) showed significant decrease $(p<0.05)$ in cows received contaminated ration with zearalenone and aflatoxins compared with control one. Our results using transrectal ultrasonography revealed that mean diameter of follicular cyst was $42.3 \pm 3 \mathrm{~mm}$ of cows received contaminated ration with zearalenone and aflatoxins while mean diameter of mature follicles was $22.1 \pm 1.7 \mathrm{~mm}$ of control cows. We concluded that zearalenone have been shown to competitive bind to oestrogen receptors and affect reproductive performance generating hormonal imbalance inducing cell toxicity, immunosuppression due to the combined effect of aflatoxins which may predispose cows to the incidence of ovarian cysts.

Key words: Mycotoxin, Reproductive performance, Dairy Cattle.

\section{INTRODUCTION}

Mycotoxin contaminations pose growing problem in animal production from the economic and toxicological point of view (Marczuk et al., 2012). The adverse effects of mycotoxins manifest both on the health status, production and reproduction in ruminants, (dairy cows specifically) (Violeta-Elana et al., 2010).

Feed stuff can be infected by more than one fungus, each of them can produce several mycotoxins consequently, and it is common that many mycotoxins occur simultaneously in feed (Sardjono et al., 1998). This combination can cause more adverse effects than a single mycotoxin due to additive or synergistic interaction.

It appears that zearalenone and aflatoxins are able to directly affect reproductive performance generating hormonal dysfunction and inducing cell toxicity, while other mycotoxins show only indirect effect on health and fertility of dairy cows, through the 
reduction of dry matter intake and decrease of gut nutrient absorption (Rossi et al., 2009).

Many phytoestrogens are now recognized as endocrine disruptor compounds capable of interfering with the synthesis, secretion, transport, binding, action or elimination of natural hormones in the body which are responsible for reproduction (RetanaMárquez et al., 2012). These compounds are structurally similar to natural estrogens such as $17 \beta-$ estradiol allowing them to bind with estrogen receptors and thereby to induce biologically detectable effects (Navarro, 2005).

Zearalenone is a mycoestrogen produced by various fungi of genus fusarium species, and it is one of the key lactones of fungal origin the biotransformation of Zearalenone in cattle involved the formation of two metabolites $\alpha$ zearalenol and $\beta$ zearalenol which are subsequently conjugated with glucuronic acid in liver. It was suggested that the glucuronic of ZEA was substantially excreted in bile to re-absorbed and metabolized further entering liver and systematic circulation via the portal supply, the reduced form of Zearalenone, zearalenol has increased estrogenic activity (Haggler et al., 2001).

Despite non-steroidal structure, Zearalenone which it activates estrogen receptors resulting in functional and morphological alteration in reproductive organs include prolonged estrus intervals decreased fertility represented by cystic ovarian disease (KuiperGoodman et al., 1987).

Aflatoxins are highly toxic metabolites produced by Aspergillus flavus, Aflatoxin B1 is converted to Aflatoxicol, the negative effect of dairy cows is not attributable to a direct activity on oocyte or embryo but it is to altered maternal homeostasis, reduction of DMI, decrease rumen motility, liver damage and reduction on immune response (Casteel, 2006) therefore there is a lack of nutrients and liver disorders that directly interfere with ovarian and uterine activity.

Reproductive toxicity in cows, infertility and hyperestrogenism have been associated with fusarium producing this mycotoxin, Zearalenone causes alteration in the reproductive tract (Mello et al., 1999) and various oestrogenic effects like decrease fertility changed weight of adrenal ,thyroid and pituitary glands change in serum levels of progesterone and estradiol, have been observed (JECFA, 2000).

So, the aim of the present study was to determine the effect of combined mycotoxicosis caused by ZEA \& Aflatoxin exposure on reproductive performance, and their relation to incidence of ovarian cyst in dairy cattle.

\section{MATERIALS and METHODS}

\section{Animals:}

The present study used 28 lactating cows kept at dairy farm in Dakahlia governorate. All animals in the present study were fed total mixed rations (TMR), nutrient concentration, met nutritional requirement for lactation according to NRC (2001). Cows were classified into two groups. First group (10 cows) were received TMR mixture where the percentage of aflatoxin and Zearalenone not exceed permissible limit which is (5 ppb and $200 \mathrm{ppb}$ respectively), (FAO, 2004) and show normal estrous behavior and have mature large follicles $>22 \mathrm{~mm}<25 \mathrm{~mm}$ in diameter and have corpus luteum. The second group (18 cows) received ration containing aflatoxin which found (19.7 ppb) and Zearalenone which was present at high levels (400 ppb), these cows exhibit "constant" estrus (nymphomania), excessive vaginal discharge, until day 45 postpartium and have ovarian cysts based on the presence of follicular structure ( $\geq 25 \mathrm{~mm}$ in diameter) with anovulation and the absence of corpus luteum

\section{Blood Samples:}

Blood samples collected via jugular vein puncture from each cow around 45 days postpartum twice weekly for two weeks after rectal palpation and ultrasosgraphy observation from Cows with at least 1 large $(\geq 25 \mathrm{~mm})$ follicular structure, no detectable signs of luteinization or corpus lutium (cyst) and Cows with at least 1 large mature follicle $(>22 \mathrm{~mm}<25 \mathrm{~mm})$, corpus lutium in ovary. Blood samples were taken in plain centrifuge tubes for serum separation and evaluation of serum progesterone $\left(\mathrm{P}_{4}\right)$, estrogen $\left(\mathrm{E}_{2}\right)$, Luteinizing hormone $(\mathrm{LH})$, triiodothyronine $\left(\mathrm{T}_{3}\right)$, thyroxin $\left(\mathrm{T}_{4}\right)$, prolactin (PRL) total protein, calcium, Inorganic phosphorus, Liver enzymatic activities alanine aminotransferase (ALT) and aspartate aminotransferase (AST) and immunologlobins (IgG, IgM, IgA).

\section{Hormonal and biochemical determination: Hormonal assay:}

Serum samples were analyzed by commercial kits solid phase radioimmunoassay for the determination of sex steroids (progesterone and estradiol-17 $\beta$ ) levels and Triiodothyronine, thyroxin and Prolactin levels the kits were purchased from DSL, (USA). Progesterone was determined according to Abraham (1981) and estradiol-17 $\beta$ estimation was carried out according to Hammond (1990), Triiodothyronine and thyroxin according to Larsen et al. (1981) and Prolactin according to Sinha (1996). Serum quantitative measurement of LH in serum by (ELISA) according to the method of Wide (1976) by using Mab IMA immune enzymatic kits-manufactured by Echobar France. 


\section{Biochemical determination:}

The obtained sera were also used for assay of total proteins according to (Sonnen wirth and Jarett 1980), calcium according to Glinder and King (1972) Inorganic phosphorus, according to Kilichling and Freibury (1951) Liver enzymatic activities alanine aminotransferase (ALT) and aspartate aminotransferase (AST) activities according to Reitman and Frankel (1957), spectrophotometrically by using standardized test-kits supplied from BioMerieux (Bains/France).

\section{Mycotoxins analysis in feed:}

Mycotoxins (aflatoxin and zearleonone) were analyzed in feed by high performance liquid chromatography (HPLC-CBC-7210H Austerila) with fluorescent detection (FLD). We offer a variety of clean up columns according to Scott (1997). Mycoyoxins (aflatoxin and zearleonone) were estimated on feed by HPLC technique according to Howell and Taylor (1981)

Determination of serum immunologlobin levels: The development of sandwich ELISA was carried out according to Erahard et al. (1992).
Microbiological and parasitological examination: in both groups.

\section{Ultrasonarolography}

Ovaries were determined by rectal palpation and ultrasosgraphy observation, (Pierson Ginther, 1988) and scanned by ultrasonography using a real-time, B mode instrument equipped with a $7.5-\mathrm{MHz}$ linear array intrarectal transducer (Exy Gyne, Version 2.01, and Noveko). Transducer of penetration power $10 \mathrm{~cm}$ Ultrasound examinations were performed by a single operator. Cows with at least 1 large $(\geq 25 \mathrm{~mm})$ follicular structure, no detectable signs of luteinization or corpus lutium, and low P4 concentrations $(<1 \mathrm{ng} / \mathrm{mL})$ were categorized, retrospectively, as having a follicular cyst. Cows with at least 1 large mature follicle $(>22 \mathrm{~mm}<25 \mathrm{~mm})$, corpus lutium in ovary and $\mathrm{P} 4$ concentrations $(>\operatorname{lng} / \mathrm{mL})$ in control group.

\section{Statistical analysis:}

The biochemical, hormonal parameters immunologlobin levels were subjected to $\mathrm{T}$ test analysis according to Senedecor \&Cochran (1982).

\section{RESULTS}

Table 1: Hormonal assay in control cows compared with those received contaminated ration with zearalenone and aflatoxins.

\begin{tabular}{lcc}
\hline & Control group & Treated group \\
\hline OESTROGEN ng/mL & $5.42 \pm 5.25$ & $6.32 \pm 1^{*}$ \\
\hline PROGESTRONE ng/mL & $1.02 \pm 0.20$ & $0.49 \pm 0.17^{*}$ \\
\hline T3 ng/mL & $62 \pm 3.4$ & $34 \pm 3.2^{*}$ \\
\hline T4 $(\mu \mathrm{g} / \mathrm{dl})$ & $6.5 \pm 0.33$ & $4.9 \pm 0.15^{*}$ \\
\hline LH ng/mL & $6.1 \pm 0.15$ & $5.2 \pm 0.51^{*}$ \\
\hline PROLACTIN ng/mL & $9.5 \pm 0.9$ & $18.5 \pm 0.95^{*}$ \\
\hline
\end{tabular}

Superscripts star within raw are significant at $(\mathrm{p}<0.05)$ Data were present as means $\pm \mathrm{SE}$

Table 2: Biochemical parameters in control cows compared with those received contaminated ration with zearalenone and aflatoxins.

\begin{tabular}{lcc}
\hline & Control group & Treated group \\
\hline AST (IU/ml) & $13 \pm 0.2$ & $49 \pm 1.5^{*}$ \\
\hline ALT (IU/ml) & $18 \pm 0.94$ & $65 \pm 0.3^{*}$ \\
\hline $\begin{array}{l}\text { PROTIEN } \\
(\mathrm{g} / \mathrm{dl})\end{array}$ & $7.39 \pm 0.45$ & $6.24 \pm 0.39^{*}$ \\
\hline CALCIUM mg/ml & $10.2 \pm 1.5$ & $7.8 \pm 0.9^{*}$ \\
\hline PHSPHORUS mg/ml & $5.5 \pm 0.15$ & $4.3 \pm 0.12^{*}$ \\
\hline
\end{tabular}

Superscripts star within raw are significant at $(\mathrm{p}<0.05)$ Data were present as means \pm SE 
Table 3: Serum immunologlobin levels in control cows compared with those received contaminated ration with zearalenone and aflatoxins.

\begin{tabular}{lccccc}
\hline \multicolumn{3}{c}{ Control group } & \multicolumn{3}{c}{ Treated group } \\
\hline IgG & IgM & IgA & IgG & IgM & $\operatorname{IgA}$ \\
\hline $1639 \pm 30.15$ & $205 \pm 9.28$ & $84.6 \pm 6.11$ & $1471 \pm 35.92^{*}$ & $132.5 \pm 3.52^{*}$ & $50.5 \pm 4.94^{*}$ \\
\hline
\end{tabular}

Superscripts star within raw are significant at $(\mathrm{p}<0.05)$ Data were present as means $\pm \mathrm{SE}$

Fig (1) follicular cystic ovary in dairy cow received contaminated zearalenone and aflatoxins

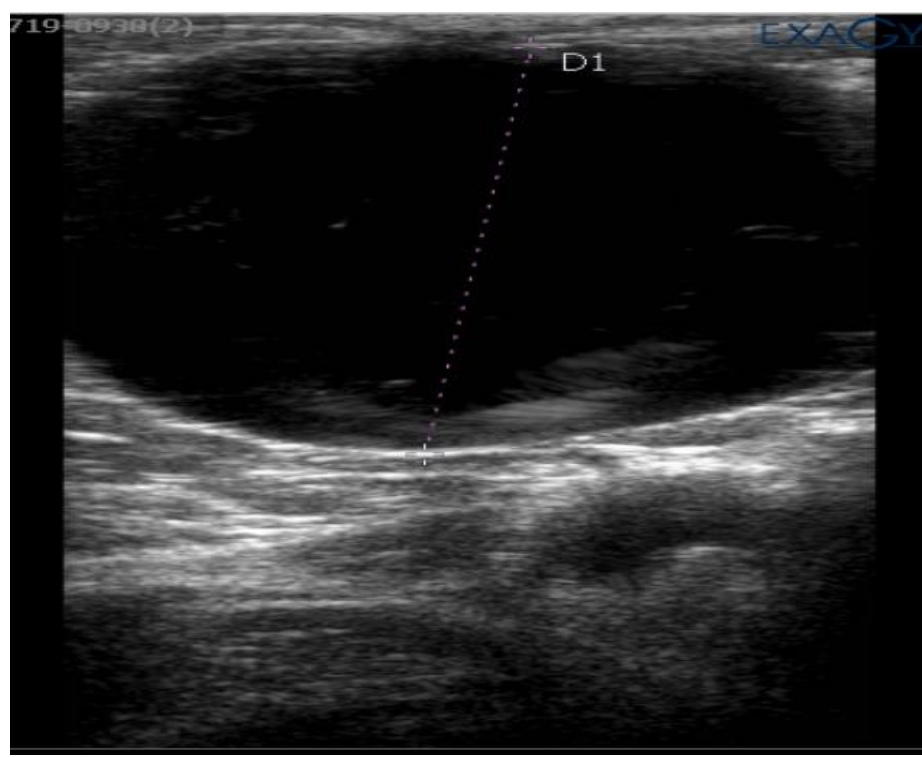

D: $47 . \mathrm{mm}$

Follicular Observations based on ultrasonography, in cows with cysts in cows received contaminated ration with zearalenone and aflatoxins. Mean diameter of cystic structure $(42.3 \pm 1.50 \mathrm{~mm})$, cows exhibit "constant" estrus (nymphomania).

Fig (2) Normal mature follicle of control group.

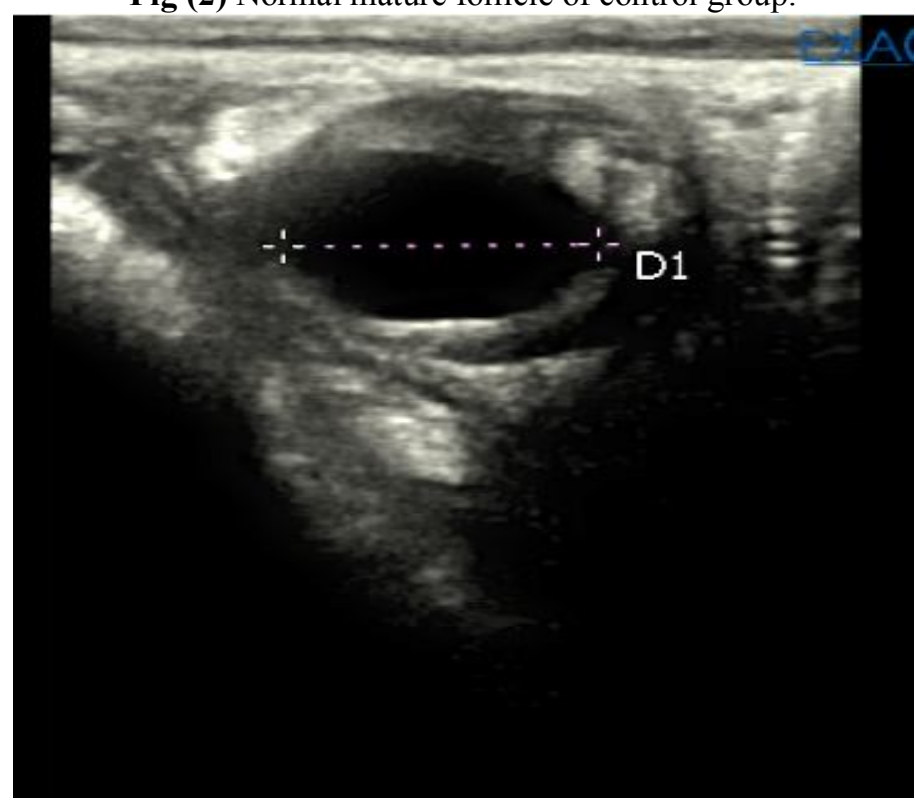

D: $23.2 \mathrm{~mm}$

Follicular Observations based on ultrasonography in normal cows with mature follicle mean diameter mature follicles $(22.3 \pm 1.71 \mathrm{~mm})$, cows show normal estrous behavior. 
All cows in the present study showed negative microbiological and parasitological examination. Regarding to our results of hormonal assay in table 1 showed significant increase $(p<0.05)$ in levels of prolactin and estrogen while levels of $\mathrm{LH}$, progestone, T3 and T4 showed significant decrease $(\mathrm{p}<0.05)$ cows received contaminated ration with zearalenone and aflatoxins in compared with control one The results of biochemical parameters present in table 2 revealed that cows received contaminated ration with Zearalenlone and aflatoxins showed a significant increase $(\mathrm{p}<0.05)$ in ALT\& AST, while total protein, calcium and phosphorus showed significant decrease $(p<0.05)$ in cows received contaminated ration with Zearalenlone and aflatoxins in compared with control one.. The results of immunological parameters (IgG, IgM, IgA) present in table 3 showed significant decrease $(\mathrm{p}<0.05)$ in cows received contaminated ration with zearalenone and aflatoxins than control one. Our results using transrectal ultrasonography in Fig 1 Mean diameter of follicular cyst was $42.3 \pm 3 \mathrm{~mm}$ of cows received contaminated ration with zearalenone and aflatoxins while Fig 2 mean diameter of mature follicles was $22.1 \pm 1.7 \mathrm{~mm}$ of control cows.

\section{DISCUSSION}

The impact of ZEA in feed on ovarian function of cattle is suggested in this study, these data confirm previous reports concerning the influence of toxic substances on cattle. The alteration of endocrine activity might induced by the cellular stress (Kolesarova et al., 2011).

In the present study our results showed a significant increase at $(p<0.05)$ in levels oestrogen and prolactin while showed a significant decrease at $(\mathrm{p}<0.05)$ in levels of progestrone LH, T3 and T4 which could be due to Zearalenlone which is a mycoestrogen produced by the fungi fusarium that may be present in moldy feed (Diekman and Green, 1992). This compounds which estrogenic activity and may play a role in cystic ovarian disease. Jakimiuk et al. (2010) revealed that Zearalenone exhibits hormonal activity which is determined by its' spatial chemical structure, concentration and time of exposure. The reproductive system is a target tissue for Zearalenone hormonal effect. Zearalenone is metabolized to hydroxyl metabolites, referred to as h-zearalenol, by ruminal protozoa, entrocytes and liver at successive stages of mycotoxin metabolism. A-zearalenol demonstrates higher affinity to estrogen receptor and it is more hormonally active than the original substance, although $\alpha$-zearalenol is absorbed in small quantities, this active substance is characterized by much higher polarity (Gajęcki et al., 2010). Zearalenlone and metabolites, including $\alpha$-zearlenol bind to estrogen receptors to initiate an agonistic/antagonistic interaction that lead to hyperestrogenism (Marczuk et al., 2012) the most characteristic symptoms include ovarian cysts and impaired oocyte development. Zearalenone is capable of modulating the level of enzymatic protein expression not only by interacting with estrogen receptors, but also as a substrate by way of competition in the absence of or at low concentrations of endogenous substrate. Its hormonal activity in the gonads is determined by concentrations at which the cellular $\mathrm{ER}_{\mathrm{S}}$ are reached, as well as by interactions with given ER type.Postpartum ovarian cysts developed when the hypothalamus and pituitary appeared to be less responsive in releasing LH under the influence of estradiol (Kesler \& Grverick., 1982) In addition, Erb et al. (1973) indicates that may be there is a deficiency in release of GnRH however, the hypothalamic -pituitary axis may not be as responsive in releasing $\mathrm{LH}$ due to elevated concentration of estradiol (Jakimiuk et al., 2009). The regulatory effect of estrogen on folliculogenesis and steroidogenesis in ovarian follicles, in particular medium-size follicles, is attributed mostly to ER $\beta$ in respect of which Zearalenone demonstrates weak estrogenic activity (Schams and Berish, 2002). Yet, most importantly, tissue response, including the ovarian response, is determined by the Zearalenone dose. By affecting the transcription activity of nuclear receptors, Zearalenone and its metabolites modify the metabolism of endogenous and exogenous compounds at ovarian level. The above receptors control the expression and the activity of phase I and II enzymes (Gajęcka et al., 2009). Zearalenone hormonal activity is manifested subject to the mycotoxin concentration and affinity to selected receptors. At low concentrations, Zearalenone may display only hormonal effects, while at high concentrations it may show both estrogenic and xenobiotic activity, thus affecting the enzymes involved in its bioconversion. (Minf et al., 2007). A factor which enhanced the Zearalenone effect on the ovaries of experimental gilts was gonad receptors for which Zearalenone showed a high affinity (Uzumeu and Zacow, 2007). Due to its similarity to estrogen receptors, Zearalenone receptors, causing estrogenic effects in pigs (Chi et al., 2010)

Confirming our results, Fink-Gremmels and Malekinejad (2007): reported that Zearalenone has a resorcyclic acid lactone structure and can cross cell membranes binding to the cytosolic $17 \beta$-estradiol $\left(\mathrm{E}_{2}\right)$ receptors and forming a Zearalenone $E_{2} R$ complex. This complex (Zearalenone- $E_{2} R$ ) is transferred into the cell nucleus and binds to specific nuclear $E_{2}$ receptors activating the gene responsible for mRNA synthesis (normally generated by $\mathrm{E}_{2}$ ). These estrogenlike effects cause anabolic and reproductive activity. Zearalenone interacts not only with both types of estrogen receptors but is also a substrate for hydroxysteroid dehydrogenases, which convert it into two stereo-isomeric metabolites, alpha-zearalenol and beta-zearalenol. Alpha-hydroxylation results in an 
increase of estrogenic potency and explains the species specific sensitivity towards Zearalenone intoxications, whereas glucuronidation capacity inactivates Zearalenone (Haggler et al., 2001)

Although doses of zearalenol required to alter pituitary secretion were greater than those required with estradiol, the resulting profiles for the hormones (LH and PRL) were similar, presumably, zearalenol and estradiol exert their effects through common mechanism that involve interaction between zearalenol, estradiol and estrogen receptors within hypothalamus and pituitary resulting in reduced sensitivity and responsiveness to the estrogen induced PRL secretion and decreased acute pituitary responsiveness to estrogenic stimulation of gonadadotropines and PRL (Elasser et al., 1983).

Regarding to thyroid function our results highlight that the decrease levels of thyroid hormones, T3 and T4 inconsistent with Sosic-Jurjevic et al. (2006) who referred to adverse effect of zearalenone which disrupt the pituitary thyroid axis leading to decrease levels of thyroid hormones, on the other hand TSH cells are estrogen responsive-ER $\alpha$ has been detected, previous studies reported that pharmacological doses of estradiol decreased the TSH immunopostive cells in female rats, other researchers have reported that higher doses of E2 inhibited TSH B mRNA levels. Moreover, Franklyn et al. (1987) reported that the biological significance of this mechanism is still unclear, thought it might affect the free thyroid hormone concentrations, resulting in altered tissue availability and disturbed feed back to the pituitary (Schutzler et al., 2007). While, Hopkin (1997) stated that aspergillus flavus, a common indoor mold, has been linked to thyroiditis and possible hypothyroidism.

Regarding to immunological parameters our results revealed that significant decrease at $(p<0.05)$ in IgA,IgG and IgM which could due to mycoestrogen (zearalenone) become the cause of the decreased efficacy of the action of environmental endogenic estrogens e.g.17 $\beta$-estradiol. They bind to (block) estrogen receptors and they probably cause the transfer of a receptor-ligand complex from cytoplasm to the nucleus and provoke synthesis of particular proteins. The phenomenon of binding (blocking) of these environmental chemical compounds to new estrogen receptors is possible (Arcaro et al., 1999). Mycoestrogen that simulate natural hormones (mimicry) block and change the effect of binding of the hormone to receptor. They can also change the metabolism of natural estrogens (Soto et al., 1995 and Withanage et al., 2001). The problem of a double action of mycoestrogen on the immunological system, which is often noticed, (Yurino et al., 2004). Ample studies have shown that hormones of the reproductive system influence the morphology of thymus and other parts of the lymphatic system. Administration of estrogens causes' thymus involution, (Ansar Ahmed et al., 1999 and Walker et al., 1999). Estrogens regulate the synthesis of serum and uterus immunoglobulins IgM, IgA and IgG, (Wira and Sandoe 1987; Makkonen et al., 2001 and Gajęcka et al., 2004). They also evoke an increase in the production of specific and non-specific antibodies (Kurup et al., 2000). From the biochemical point of view and taking interactions into account it can be concluded that both those forms are not clear. It is likely that hormones and cytokines serve a very important function in the transmission of information between the two systems: the reproductive and the immune one (Krakowski et al., 2004). This probably strict co-operation assumes that the influence of the natural estrogens on the tissues in the reproductive system can also affect the immunological system. It is still controversial, however, if this result is produced by the direct or indirect action of the natural estrogens. It should also be considered if the immunological system is a real aim for all EDs or environmental estrogens in particular In addition Fusarium mycotoxins appear to act at different cellular and molecular levels that affect viability, proliferation and differentiation of immune system cells (George et al., 2008), these effects may be a result of inhibited protein synthesis (Desjardins et al., 2006) or impairment of the activity or secretary functions of immune system cells (Oswald et al., 2005) as well as synthesis of cytokines that regulate the communication net work of immune system (Swamy et al., 2004). In addition aflatoxins can cause organs damage or immunosuppression. Recent investigations have reported that several alterations of immunological parameters were found in vitro associated with Zearalenone concentrations (Marin et al., 1996), the depressed immunological status such as IgG, IgM and serum globulins had higher values.

Concerning to our biochemical results, some biochemical parameters exceeded the normal physiological level which may be the results of a defense reaction of the organism to the dairy cows the biochemical parameters change their values which are characteristic for certain pathological affections that a biochemical panel is recommended each time the suspicion of mycosis and myctoxicosis (Simion et al., 2010). Moreover Zearalenone and aflatoxin have been shown to be hepatotoxic haematotxic and genotoxic our results of protein level showed significant deceased at $(\mathrm{p}<0.05)$ in group received contaminated ration with Zearalenone and aflatoxin compared with control one (Doll et al., 2003 and Cheng et al., 2006) which could due to inhibition of protein synthesis at cellular level and will therefore predominantly damage quickly proliferating cells as found in the immune system (Goyards et al., 2006). Moreover aflatoxin inhibits protein synthesis and cell proliferation (Sharma, 1993). This inhibition may not 
be the primary mechanism involved in their immunotoxic effects; but may have selective effects on various subpopulations of lymphocytes. Since immunoglobulins are proteins, a decrease in total proteins and globulins might result in reduced antibody production which ultimately results in decreased immunity. On the other hand, Fusarium mycotoxins directly affect globulin synthesis in the liver and compromise the immune response of cows (Rotter et al., 1994).

Blood parameters might be used for an additional estimation of toxic effects on live animals. It is assumed that elevated activities of serum enzymes such as alanine aminotransferase (ALT) and aspartate aminotransferase (AST) might reflect the organ damage (Cheng et al., 2001; Cheng et al., 2006 and Chytor et al., 2010) mycotoxins induced hepatotoxicity (Bergsjo et al., 1993). The alterations of liver enzyme activities due to abnormal excretion of liver metabolites due to mild liver damage (Chytor et al., 2010) and hepatocellular cytoplasmic vacuolation with early portal fibrosis and bile duct hyperplasia (Harvey et al., 1989) In the studies of Mikami et al. (2004) the results indicated that Fusarium induces apoptosis through the caspase-3 activation pathway and causes functional disorder in hepatocytes.

Regarding the estimated levels of $\mathrm{Ca}, \mathrm{Ph}$, in of cows received contaminated ration with zearalenone and aflatoxins animals. They were significantly decreased compared to that clinically normal cows. The reported lower levels could be attributed to decrease food intake and absorption due to affection similar results were reported by Ramos et al. (1996), Amal and Abo El-Maged, (2003), Dede et al. (2003) and Aatish et al. (2007). These results indicate Liver and tissues destruction due to aflatoxin similar results were recorded by Harvey et al. (1995), Fernandez et al. (1997), Magda (2001), Manal et al. (2004), and Pinar et al. (2009). However, there are link between mineral status and infertility. Gonadotropin-releasing hormone stimulation to $\mathrm{LH}$ release from pituitary gland involve calcium -dependent mechanism. No cAMP is involved and LH is not released in the absence of calcium or blocking agent (Hurley and Doane, 1989). Phosphorus deficiency induced irregular estrus, anestrus, decreased ovarian activity, increased incidence of cystic follicles and generally depressed fertility (Morrow, 1980).

We concluded that zearalenone have been shown to competitive bind to oestrogen receptors and affect reproductive performance generating hormonal imbalance inducing cell toxicity, immunosuppression due to the combined effect of aflatoxins which may predispose cows to the incidence of ovarian cysts.

\section{ACKNOWLEDGEMENT}

I am reaching this goal thanks to the infinite generosity of Dr: Manal Galal Chief Researcher in Biology department in Reproduction Research Institute Giza. I thank very much for Dr Hanny Hassan Agent Institute for Graduate studies and researches and Dr Mohammed Zenhome in ultrasonography unit in Reproduction Research Institute Giza for the ultra effort to end this work.

\section{REFERENCES}

Astish, Hu.; Sindhu, Z.; Iqbal, Z.; Jabbar, A. and Tasawar, Z. (2007): Prevalence of sheep Mange in District Dera Ghazi Khan (Pakistan) and Assocated Hematological / Biochemical Dusturbance int. J. Agric. Biol., 9(6): 917-920.

Abraham, G.E. (1981): The application of natural steroid radioimmunoassay to gynecologic endocrinology. In: Radioassay Systems in Clinical Endocrinology (Abraham, G.E. Ed). Basel: Marcel Dekker. pp. 475.

Arcaro, K.F.; O'Keefe, P.W.; Yang, Y.; Clayton, W. and Gierthy, J.F. (1999): Antiestrogenicity of environmental polycyclic aromatic hydrocarbons in human breast cancer cells. Toxicology 133, 115-127.

Amal, R. Toos and Abo El-Maged, M.K. (2003): Biocheical change in sera of lactating goat affecting with aflatoxicosis. Vet. Med. J. Giza 51 (4): 587-597.

Ansar Ahmed, S.; Hissong, B.; Verthelyi, D.; Dinner, K.; Becker, K. and Karpuzoglu-Sahin, E. (1999): Risk of autoimmune disease. Environ. Heath Perspective, 107: 681-686.

Bergsjo, B.; Langseth, W.; Nafstad, I.; Jansen, J.H. and Larsen, H.J. (1993): The effects of naturally deoxynivalenol-contaminated oats on the clinical condition, blood parameters, performance and carcass composition of growing pigs, Vet. Res. Commun. 17: 283-294.

Magda, Sh.T. Farag. (2001): Aflatoxicosis as predisposing cause of high mortalities in Egyptian goat. J. Egy. Vet. Med. Ass. 61 (5) 171-278.

Makkonen, K.; Viitala, K.I.; Parkkila, S. and Niemalä, O. (2001): Serum IgG and IgE antibodies against mold-derived antigens in patients with symptoms of hypersensitivity. Clinical. Chemical. Acta, 305: 89-98.

Casteel, S.W. (2006): "Reproductive toxicants Mycotoxins" in Current Therapy in Large Animal Theriogenology, Ed. SaundersElsevier, page. 425.

Chaytor, A.C.; See, M.T.; Hansen, J.A.; de Souza, A.L.P.; Middleton, T.F. and Kim, S.W. (2010): Effects of chronic exposure of diets with 
reduced concentrations of aflatoxin and deoxynivalenol on growth and immune status of pigs J ANIM SCI, 89: 124-135.

Cheng, Y-H.; Wenng, C-F.; Chen, B-J. and Chang, M. (2006): Toxicity of different Fusarium mycotoxins on growth performance, immune responses and efficacy of a mycotoxin degrading enzyme in pigs Anim. Res. 55 579590579

Cheng, Y.H.; Shen, T.F.; Pang, F. and Chen, B.J. (2001): Effects of aflatoxin and carotenoids on growth performance and immune response in mule ducklings, Comp. Biochem. Phys. C 128: 19-26

Chi, F. Broomhead and Chung, C. (2010): Zearalenone toxicity, a significant factor in reduced swine fertility and reproduction. Technical Bulletin (3), 10: 105-108.

Dede, S.; Deger, Y. and Deges, S. (2003): Serum profile of calcium, phosphorus, copper and zinic in heallty and lice infsted gosts idan vet. J., 80: 150-151.

Desjardins, A.E. (2006): Mechanism of action of trichothecenes. In: Desjardins AE, Ed. Fusarium Mycotoxins Chemistry, Genetics and Biology. Minnesota: APS, pp: 53-54

D, Mello, J.P.F.; Placinta, C.M. and Macdonald, A.M.C. (1999): Fusarium mycotoxin a review of global implication for animal health, welfare and productivity. Anim. feed Sci. Technol.80, 183-208.

Diekman, M.A. and Green, M.L. (1992): Mycotoxins and reproduction in domestic livestock. J. Animal. Sci. 70: 1615-1627.

Doll, S.; Danicke, S.; Ueberschar, K.H.; Valenta, H.; Schnurrbusch, U.; Ganter, M.; Klobasa, F. and Flachowsky, G. (2003): Effects of graded levels of Fusarium toxin contaminated maize in diets for female weaned piglets, Arch. Tierernahr. 57: 311-314.

Erhard, D.M.; Vovquistor, D.I.; Schemer's, Jungling, A.; Kaspers, B. and PandKuhmann, R. (1992): Development of specific enzymes linked immunosorbent antibody assay for detection of chicken immunologic monoclonal antibodies Poultry Sci., 71: 302-310

Elasser, T.H.; Bolt, D.J.; Bradley, B.D. and Roper, M. (1983): Lutiezing hormone, follicle stimulating hormone and prolactin secretion in ewes and wethers after zeranol or estradiol injection J. Anim. Scie, 57: 2, 443-448.

Erb, R.E.; Monk, E.L.; Callahan, C.J. and Mollet, T.A. (1973): Endocrinology of induced ovarian follicular cysts. J. Anim. Sci, 37: 310.

FAO, Food and Agriculture Organization (2004): Worldwide regulation for mycotoxins 1995.A.compendium FAO Food and Nutrition, Rome, Italy.

Fink-Gremmels, J. and Malekinejad, H. (2007): Clinical effects and biochemical mechanisms associated with exposure to the mycoestrogen zearalenone. Animal Feed Science and Technology, 137: 326-341.

Franklyn, J.A.; Wood, D.F.; Alfour, N.J.; Ramasden, D.B.; Docherty, K. and Sheppard, M.C. (1987): Modulation by oestrogen of thyroid hormone effect on thyrotrophin gene expression. J. Endocrinol, 115: 53-59.

Fenandez, A.; Belio, R., Ramos, JJ.; Saez, MC. and Sanz, T. (1997): Aflatoxins and their metabolies in the tissues, faeces and urine from lambs feeding on an aflatoxins contaminated diet. J. Sci. Food Agric., 79 (2): 161-168.

Gajęcki, M. (2010): Mikotoksykozyu bydła. Lecznica Dużych Zwierząt, 5: 108-112

Gajęcka, M.; Jakimiuk, E.; Skorska-Wyszyńska, E.; Zielonka, Ł.; Polak, M.; Paluszewski, A.; Rybarczyk, L. and Gajęcki, M. (2004): Influence of zearalenone micotoxicosis on selected immunological, hematological and biochemical indexes of blood plasma in bitches. Polish. J. Vet. Sci., 7: 177-180.

Gajęcka, M.; Jakimiuk, E.; Zielonka, L.; Obremski, K. and Gajecki, M. (2009): The biotransformation of chosen Mycotoxins. Polish Journal of Veterinary Sciences, 12: 293303.

Gajęcki, M.; Gajęcki, M.; Jakimiuk, E.; Zielonka, Ł. and Obremski, K. (2010): Zearalenone undesirable substance. In: Rai Mahendra, Varma Ajit, (Eds) Mycotoxins in food, feed and bioweapons. Springer-Verlag Berlin Heidelberg, pp 131-144.

George, N.; Girgis, S.S.; John, R.; Barta-Herman, J.B. and Trevor, K.S. (2008): Immunomodulatory Effects of Feed-Borne Fusarium Mycotoxins in Chickens Infected with Coccidia. Experimental Biology and Medicine, 233: 1411-1420.

Glinder, E.M. and King, J.D. (1972): Rapid calorimetric determination of calcium in biological fluids with methylene blue. Am. J. Clin. Path., 58: 376-382.

Goyards, T.; Anicke, S.; Grove, N.; Tiemann, U. and Rothkoter, H.J. (2006): Methodical aspects of in vitro proliferation of lymphocytes when exposed Deoxynivalenol(DON). In Landbauforschung Volkenrode, (56): 2-3, 139148.

Haggler J.R., W.M.; Towers, N.R.; Mirocha, C.J.; Eppley, R.M. and Bryden, W.L. (2001): Zearalenone: Mycotoxins or mycoestrogen? In: Summer ell, B.A., Leslie, J.F., Backhouse, D., Bryden, W.L., Burgess, L.W. (Eds.), Fusarium. Paul E. Nelson Memorial Symposium. APS Press, St. Paul, Minn.

Hammond, G.L. (1990): Molecular properties of corticosteroid binding globulin and the sex. Steroid binding proteins. Endocrine Rev., 11: 65 . 
Hurley, W.L. and Doane, R.M. (1989): Recent developments in the roles of vitamins and minerals in reproduction. J. Dairy Sci, 72: 784804.

Harvey, R.B.; Kubena, L.F.; Phillips, T.D.; Huff, W.E. and Corrier, D.E. (1989): Prevention of aflatoxicosis by addition of hydrated sodium calcium aluminosilicate to the diets of growing barrows. American Journal of Veterinary Research, 50, 416-420.

Harvey, R.B.; Edrington, T.S.; Kubena, L.F.; Elissalde, M.H.; Corrier, D.E. and Rottinghous, D.E. (1995): Effect of aflatoxin and diacetoxyscirpenol in ewe lamb $s$ .Bull.Environ.Contam.toxicol., 54(3): 325-330.

Howell, M.V. and Taylor, P.W. (1981): Determination of Aflatoxins, ochratoxins A, and zearalenone in mixed feeds, with detection by thin layer chromatography or high performance liquid chromatography. J. Assoc. of. Analy. Chem.; 64(6):1356-1363.

Hopkins, S. (1997): Thyroid disease and hypothyroidism may also result from chronic subcutaneous candidiasis; a rare skin disorder caused the yeast Candida. Dermatology, J, 136(1): 24-29.

Jakimiuk, E.; Gajęcki, M.; Jana, B.; Brzuzan, P.; Zielonka, L.; Skorska-Wyszynska, E. and Gajęcki, M. (2009): Factors determined sensitivity of prepubertal gilts to hormonal influence of zearaleonone. Polish Journal of Veterinary Sciences, 12: 149-158.

Jakimiuk, E.; Rybarczyk, L.; Zwierzchowski, W.; Obremski, K.; Gajecka, M.; Zielonka, L. and Gajęcki, M. (2010): Effect of experimental long- term exposure to low-dose zearalenone mycotoxicosis on selected morphological parameters of reproductive tract in sexuallyimmature gilts.

JECFA. (2000): Zearalenone .In:Jiont FAO/WHO Expert Committee on Food Additive(Ed),Safety evaluation of certain food additives and contaminants. WHO/ FAO food additives Series 44. IPCS-International Programme on Chemical Safety. WHO, Geneva.

Kesler, D.J. and Grverick. H.A. (1982): Ovarian cysts in dairy cattle J. Anim. Sci. (55):5, 1148-1159.

Kiliching, H. and Freiburg, P.R. (1951): Inorganic phosphorus and alkaline phosphatase in serum in klinphotometric. 3rd ED. Wiss. Val- Ges $\mathrm{MBH}$, Stuttgart.

Kolesarova, A.; Cpcarova, M.; Maruniakova, N.; Bakova, Z.; Toman, R.; Nath, S. and Alexander. (2011): Deoxynivalenol-induced animal ovarian signaling: proliferation and apoptosis. J.Micro.Biotech.and food Sci, 1(3): 323-332.

Krakowski, L.; Kostro, K.; Krakowska, I. and Wrona, Z. (2004): Immunomodulatory role of cytokines in animal reproduction. Medycyna Wet., 60: 1034-1038 (in Polish; English abstract).

Kurup, V.P.; Shen, H.D. and Banerjee, B. (2000): Respiratory fungal allergy. Microbes. Infect., 2, 1101-1110.

Kuiper-Goodman, T.; Scott, P.M. and Watanabe, H. (1987): Risk assessment of the mycotoxin zearalenone. Regul. Toxicol. Pharmacol. 7: 253-306.

Larsen, P.R.; Silva, J.E. and Kaplan, M.M. (1981): Relationships between circulating and intracellular thyroid hormones: physiological and clinical implications. Endocrine Rev. 2: 87-102.

Manal, A. Hanssan; Kmel, H.H. and Hassan, A.A. (2004): Clinicopathologicl studies on caprine aflatoxicosis. Vet. J. Giza 52(4): 535-550.

Marczuk, J.; Obremski, K.; Lutnicki, K.; Gajęcka, M. and Gajęcki, M. (2012): Zearalenone and deoxynivalenol mycotoxicosis in dairy cattle herds Polish Journal of Veterinary Sciences Vol. 15, No. 2 (2012), 365-372.

Minf, W.; Pascussi, J.M.; Pillon, A.; Escande, A.; Bartegi, A.; Nicolas, J.C.; Cavallies, V.; Duchesne, M. and Balaguer, P. (2007): Estrogens and antiestrogens activate hPxR. Toxicol. Lett, 170: 19-29.

Marczuk, J.K.; Obremski, K. Lutnicki1 and Gajêcka1, M. (2012): Zearalenone and deoxynivalenol mycotoxicosis in dairy cattle herds. Polish Journal of Veterinary Sciences. (15):2, 365-372.

Mikami, O.; Yamamoto, S.; Yamanaka, N.; Nakajima, $Y$. (2004): Porcine hepatocyte apoptosis and reduction of albumin secretion induced by deoxynivalenol, Toxicol. 15) 241- 249.

Marin, L.; Mutha, J.; Dong, W. and Pestka, J.J. (1996): Effects of mycotoxin on cytokine production and proliferat in EJ-4thymoma cells. J. Toxicol. Environ. Health48, 379-396.

Morrow, A.A. (1980): Current therapy in theriogenology $1^{\text {st }}$ Edn,W.B.Saunders Co., Philadelphea p.449.

Navarro, M.C. (2005): Mecanismo de acción de las isoflavonas. Ginecología Obstetricia Clínica. 6: 159-165.

NRC:National Research Council(2001): Nutrient requirements of dairy cattle. 7 th. Ed.242-248

Pierson, R.A. and Ginther, OJ. (1988): Ultrasonic image of the ovary and uterus in cattle. Therioginology, 29: 21-37.

Pinar Tranritanir; Nalan Ozdal; Cennet Ragbeti; Ibrahim Yourk; Ebubekir Ceylan and serder Deger. (2009): Some Biochemical Parameters and vitamins levels in the Hair Goats Naturally Mix-infested with Endo and Ectoparasites (lice (linognathus africanus) and Trichostrongylidae.sp) Journal of animal and veterinary Advances 8(3): 590-594. 
Oswald, I.P.; Marin, D.E.; Bouhet, S.; Pinton, P.; Taranu, I. and Accensi, F. (2005): Immunotoxicological risk of mycotoxins for domestic animals. Food and Contam, 22:354360.

Ramos, J.J.; Fernandez Isaez, A.; Sonz, M.C. and Marco, M.C. (1996): Effect of aflatoxicosis on blood mineral constituents of growing lams .Small Ruminant Res, 21: 233-238.

Reitman, S. and Frankel, S. (1957): Colorimetric method for determination of serum AST and ALT. Am. J. clin. Pathol, 28: 56-58.

Retana-Márquez, S.; Hernandez, H.J.; Flores, A.; Munoz, M.G.; Duarte, G.; Vielma, J.; FitzRodríguez, G.; Ilda Graciela, I.F.; Keller, M. and José Delgadillo, J.A. (2012): Effects of phytoestrogens on mammalian reproductive physiology Tropical and Subtropical Agro ecosystems, (15): 1:129-145.

Rossi Federico; Right Federico; Fuochi Sara and Quarantelli Afro (2009): Effects of Mycotoxins on Fertility Of Dairy Cow. Ann. Fac. Vet. Med. diParma, (29): 153 -166.

Rotter, B.A.; Thompson, B.K.; Lessard, M.; Trenholm, H. and Tryphonas, L.H. (1994): Influence of low-level exposure to Fusarium mycotoxins on selected immunological and hematologicalm parameters in young swine, Fund. Appl. Toxicol. 23: 117-124.

Sardjono, N.A.; Yasmashita, A. and Yoshizawa, T. (1998): Natural co-occurrence of aflatoxins and Fusarium mycotoxins (fumonisins, deoxynivalenol, nivalenol and zearalenone) in corn from Indonesia. Food Addit. Contamination, 15: 337-384

Schams, D. and Berisha, B. (2002): Steroids as local regulators of ovarian activity in domestic animals. Domest. Animal Endocrinol, 23: 53-65.

Schutzler, C.; Gotthardt, I.; Hofmann, P.J.; Radovic, B.; Kovacs, G.; Stemmler, L.; Nobis, I.; Bacinski, A.; Mentrup, B.; Ambrugger, P.; Ruters, A.; Alndowicw, L.K.; Christoffel, J.; Jarry, H.; Seidlova-Wutke, G.; Wuttke, W. and Kohrle, J. (2007): Endocrine disruptors and the thyroid gland - a combined invitro and invivo analysis of potential new biomarkers. Environ.Health.Perspect, 115(1): 77-83.

Scott, P.M. (1997): Natural Toxins. In: Cunnif, P. (Ed). Official Methods of Analysis Association of official Analytical Chemists Gaithersburg, Mryland, 970.44, 971.22, 986.16.

Sharma, R.P. (1993): Immunotoxicity of Mycotoxins. J. Dairy Sci. 892-897.

Sinha, Y.N. (1996): Structural variant of Prolactin: Occurrence and physiological significance. Endocrinol, 16: 345-369.

Snedecor, G.W. and Cochran, W.C. (1980): Statistical Methods. 8th ed., Iowa. State Univ., Press Ames Iowa, USA.
Simion, V.E.; Gheorghe Pârvu; Elena Potecea; Luiza Bădic and Monica Pârvu (2010): Alteration of some Biochemical and Haematological Parameters in the Dairy Cows Due to the Intake of Mycotoxin Contaminated Feeds Simion V. E. et al./Scientific Papers: Animal Science and Biotechnologies, 43 (1) 100.

Sonnerwirth, A.C. and Jarrett, L.D. (1980): Gradwal's (clinical laboratory Methods and diagnosis). Vol. 18th Ed. Pp. 258-259. The C.V Mosby Co, ST, Louis, Toronto, London.

Sosic-Jurjevic, B.; Filipovic, B.; Milosevic, V.; Nestorovc, N.; Negic, N. and Sekulic, $M$. (2006): Effects of ovariectomy and chronic estradiol administration on pituitary -thyroid axis in adults rats. Life Sci, 79: 890-900.

Soto, A.M.; Sonnenschein, C.; Chung, K.L.; Fernandez, M.F.; Olea, N. and Serrano, F.O. (1995): The E-SCREEN assay as a tool to identify estrogens: an update on estrogenic environmental pollutants. Environ. Health Perspective, 103: 113-122.

Swamy, HVLN; Smith, TK.; Karrow, NA. and Boermans, HJ. (2004): Effects of feeding blends of grains naturally contaminated with Fusarium mycotoxins on growth and immunological parameters of broiler Chickens. Poult. Sci. 83: 533-543,

Uzumeu, M. and Zacow, R. (2007): Developmental exposure to environmental endocrine disruptors; consequences within the ovary and female reproductive function. Reprod .Toxicology, 23: 337-352.

Violeta-Elena Simion; Gheorghe Pârvu; Elena Potecea; Luiza Bădic and Monica Pârvu. (2010): Alteration of some Biochemical and Haematological Parameters in the Dairy Cows Due to the Intake of Mycotoxins Contaminated Feeds. Simion V. E. et. al. /Scientific Papers: Animal Science and Biotechnologies, 43 (1): 100- 110.

Walker, C.; Ansar Ahmed, S.; Brown, T.; Ho, S.M.; Hodges, L.; Lucier, G.; Russo, J.; Weigel, N. and Weise, T. (1999): Interindividual, and tissue specificity in endocrine signaling. Environ. Health Perspective, 107: 619-624.

Wide, L. (1976): Human pituitary gonadotrophins: Hormone assays and their clinical application, pp 87-140 Ed. J. Lorain, ET. Bell Churchill Livingstone, Edinburg, London and New York, USA.

Wira, C.R. and Sandoe, C.P. (1987): Specific IgA and $\operatorname{IgG}$ antibodies in the secretions of the female reproductive tract: effects of immunization and estradiol on expression of this response in vivo. J. Immunology., 138: 4159-4164

Withanage, G.S.; Murata, H.; Koyama, T. and Ishiwata, I. (2001): Agonistic and antagonistic effects of zearalenone, an estrogenic 
mycotoxin, on skin, HHUA, and HepG2 human cancer cell lines. Vet. Hum. Toxicol, 122: 1706-1716.

Yurino, H.; Ishikawa, S.; Sato, T.; Akadegawa, K.; Ito, T.; Ueha, S.; Inadera H. and Matsushima,
K. (2004): Endocrine disrupters (environmental estrogens) enhance autoantibody production by B1 cells. Toxicol. Sci., 81: 139-147

\section{تاثير السموم الفطرية على الكفاءة التناسلية فى الابقار الحلابة \\ منى عبل المنعم ، طه غطاس ، امل الليل ، محمد ذ/با}

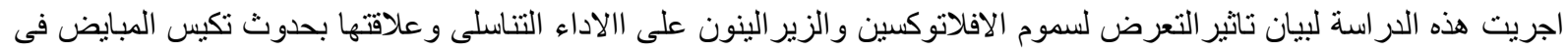

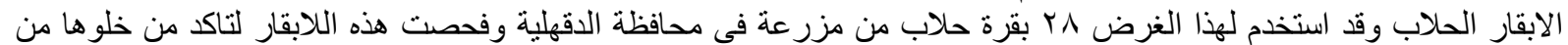

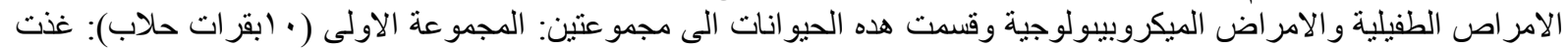

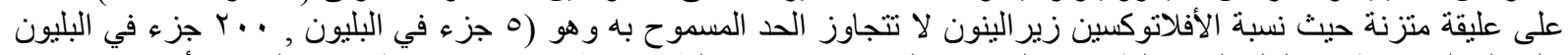

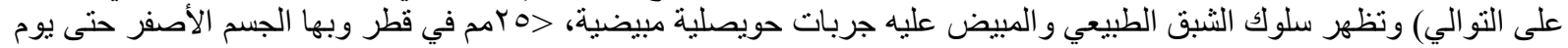

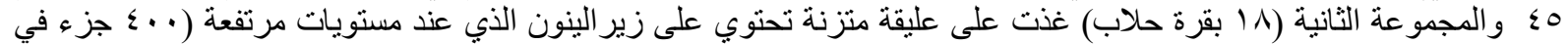

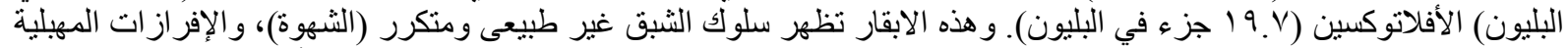

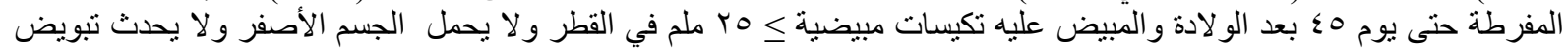

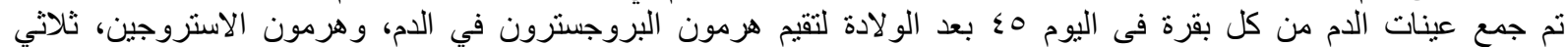

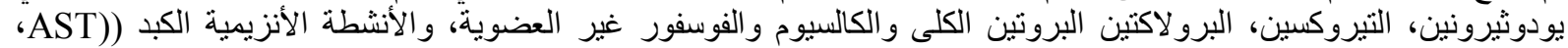

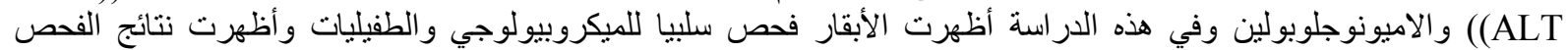

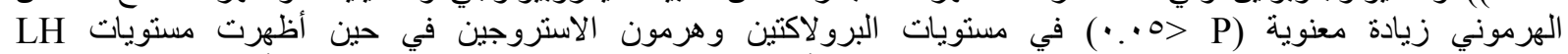

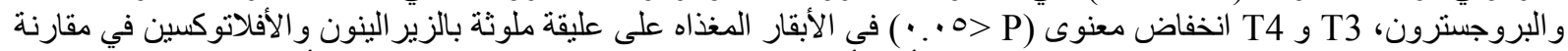

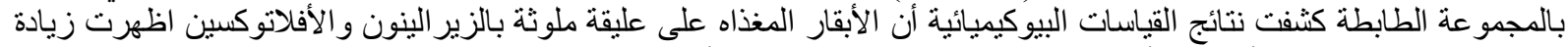

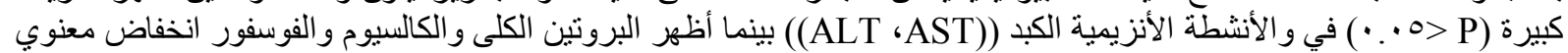

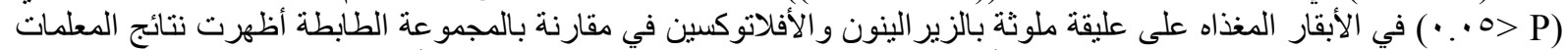

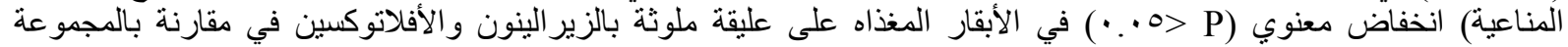

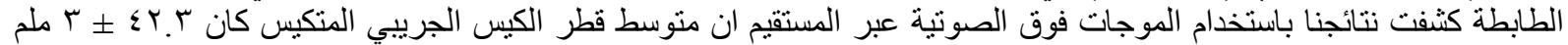

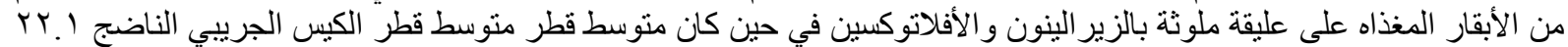

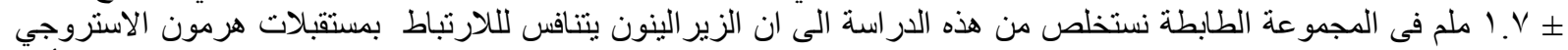

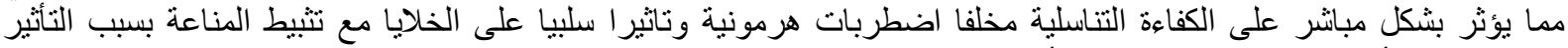
المشترك مع الأفلاتوكسين الذي قد يؤ هب الأبقار إلى حدوث التكيسات المبيضية. 